\title{
The Artist Behind the Winter Dance Logo: Smoker Marchand
}

\section{By Maura Laverty}

Y ou might recognize the artist's name from the 1992 Spokane SRM Annual Meeting logo. Mr Smoker Marchand, from the Colville Confederated Tribes in Washington, is an accomplished artist who utilizes many media and who attributes much of his inspiration to his seven children and 13 grandchildren. His art was chosen to represent the Winter Dance theme for the 2012 SRM Annual Meeting in Spokane, Washington, 29 January-3 February 2012.

During the week, he is a planner for the Colville Tribal Planning Department, where he has worked for 33 years. $\mathrm{He}$ is grateful, because it has allowed him to provide for his large family.

Marchand creates huge pieces of art after work, and on weekends. He says he could probably make a living as an artist if he lived in a metropolitan are, "But I like where I'm at." He lives close to his family, and the ancestral lands of his Arrow Lakes Band, one of the 12 tribes represented by the Colvilles, which stretch far into Canada.

"Virgil 'Smoker' Marchand was born in Inchelium and grew up in Omak with his grandmother, Mary Marchand," writes K. C. Mehaffey, staff writer for the Wenatchee World, who interviewed Smoker and wrote several articles about him for the 26 March 2011 edition of the newspaper. ${ }^{1,2}$

Fellow artist Dorothy Tinning adds, "The sculptor, Smoker Marchand, was given his Indian name 'Spa Poole' which means smokey, or smoke in his language, by his grandmother." ${ }^{\prime i}$ From her, he learned the language and history of his people. Encouraged by his brother to pursue art, Smoker attended the Institute of American Indian Arts in Santa Fe, New Mexico, graduating in 1971. The immersion in this outstanding art school brought out something special in Smoker that he never knew was there. Today, however,

'Fellow artist, Dorothy Tinning, Penticton, British Columbia, Canada, has such a high regard for Smoker Marchand's sculptures that she titled one of her acrylic on canvas paintings, A Tribute To Smoker Marchand, which may be seen on her website, www.dorothytinning.com. Smoker Marchand was also the guest of honor at her first art exhibition at the Nk'Mip Desert Cultural Centre in Osoyoos, British Columbia, in 2008. he uses techniques that were basically self-taught. His art incorporates a rare beauty, a balance, and an exquisite unique form.

He works in a shop next to his house, below sage-covered foothills where coyotes sing. An uncle does most of his welding. Behind his shop, there is a barn with horses, and in the field next to it, a racetrack, where his wife Anne teaches young jockeys to ride.

Smoker Marchand was commissioned by Chief Clarence Louie, of the Osoyoos Indian Band, to create metal sculptures to honor the Okanagan native history. These sculptures have attracted international attention, as they evoke the history of the Okanagan people and their rich tradition of being connected to the land. The sculptures reflect the changing light and cycle of the seasons in the surrounding grasslands of sage and antelope brush.

According to Mehaffey, Smoker has

illustrated children's books, and in November of 2010, a poster

of one of his pen-and-ink drawings was distributed to nearly

3,000 Natural Resources Conservation Service offices around the

country for American Indian Heritage Month. He designed the

Colville tribe's flag and a logo for all of its departments.

He has nine limited-edition bronze sculptures and 11 limited-edition prints. He also creates works that aren't designed to last, such as ice sculptures.

In 1992, he entered the art show at the United Tribes International Powwow in Bismarck, North Dakota, because he wanted to know how he fit in the art world. He won the Best of Show and People's Choice awards.

Marchand was ready for a change when he journeyed into steel sculpture.

\section{You had to sell yourself with paintings, and you always had to come up with a name. People would ask why you did the painting. "What does it mean? What do you call it?" With steelwork, I don't get that experience.}

Now, people see his work, and come to him to commission a piece. 
Marchand didn't create all these sculptures for the money, although he's sometimes tested by that assertion when he doesn't get paid. But in theory, his reason is a simple one: "If you have a gift, you should share it with everybody as much as you can."

The Pacific Northwest Section of SRM is pleased to share the gift of Smoker Marchand for the Spokane 2012 Annual Meeting. We hope you appreciate his art as much as we do.

\section{References}

1. Mehaffey, K. C. 26 March 2011. Marchand has designed ice sculptures, eyeglasses. Wenatchee World. Available at: http://www.wenatcheeworld.com/news/2011/mar/26/ marchand-has-designed-ice-sculptures-eyeglasses/. Accessed 18 July 2011.

2. Mehaffey, K. C. 26 March 2011. Colville artist's sculptures chosen for Beebe Springs Natural Area. Wenatchee World. Available at: http://www.wenatcheeworld.com/news/2011/mar/26/ colville-artists-sculptures-will-be-at-beebe/. Accessed 18 July 2011.

Maura Laverty is the Range and Invasive Species Program Manager for the Okanogan-Wenatchee National Forest, and Cochair of the Publicity Committee for the 2012 SRM Annual Meeting in Spokane.

\section{Winter Dance-2012}

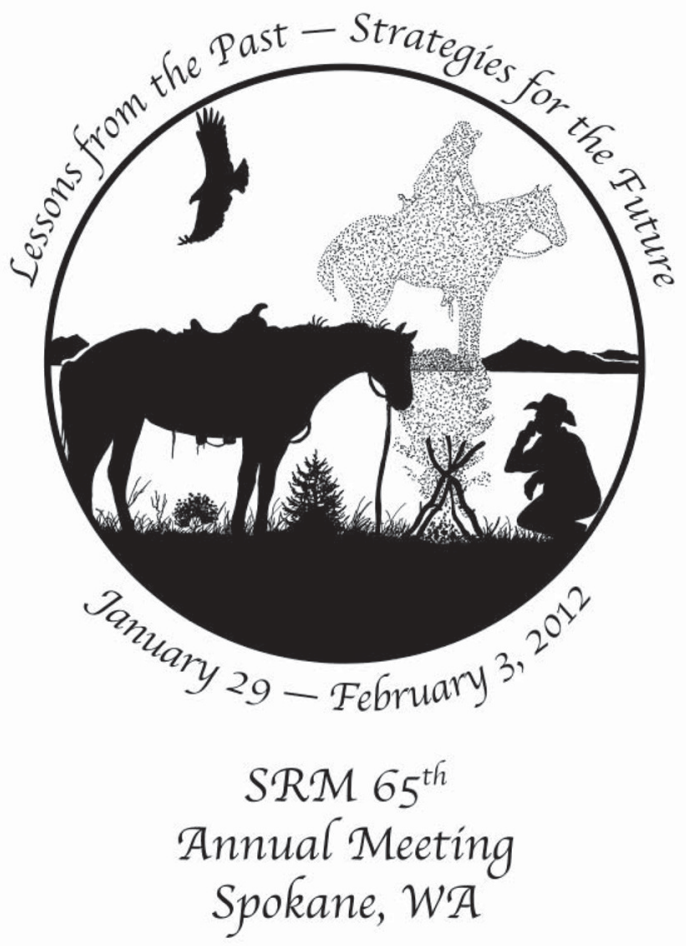

